\title{
3-Methyl-5-nitropyrimidin-4(3H)-one: an excellent precursor for functionalized nitroenamines
}

\author{
Nagatoshi Nishiwaki, Yukiko Mizukawa, Reiko Terai, Yasuo Tohda ${ }^{\dagger}$, and Masahiro \\ Ariga* \\ Department of Chemistry, Osaka Kyoiku University, ${ }^{\dagger}$ Division of Natural Science, Osaka \\ Kyoiku University, Asahigaoka 4-698-1, Kashiwara, Osaka 582-8582, Japan \\ E-mail: nishi@cc.osaka-kyoiku.ac.jp
}

(received 15 Nov 99; accepted 25 Apr 00; published on the web 03 May 00)

\begin{abstract}
The reaction of 3-methyl-5-nitropyrimidin-4(3H)-one (1) with aliphatic and aromatic primary amines effectively afforded nitroenamines $\mathbf{4}$ having a carbamoyl group. When 1,2diaminobenzenes were used, benzimidazoles 10 were obtained besides 4 . Synthetic utility of the functionalized nitroenamines was also demonstrated in the conversion of nitroenamine $\mathbf{4 b}$ to polysubstituted pyridone 12.
\end{abstract}

Keywords: Nitroenamines, 3-methyl-5-nitropyrimidin-4(3H)-one, benzimidazoles

\section{Introduction}

Highly electron-deficient 3-methyl-5-nitropyrimidin-4(3H)-one (1) has ultifunctionality, such as nitroalkene, $\alpha, \beta$-unsaturated amide, amidine and so on. Pyrimidinone $\mathbf{1}$ has been proved ${ }^{1-4}$ to be good synthetic equivalents of polyfunctionalized units for construction of azaheterocycles (Scheme 1). 


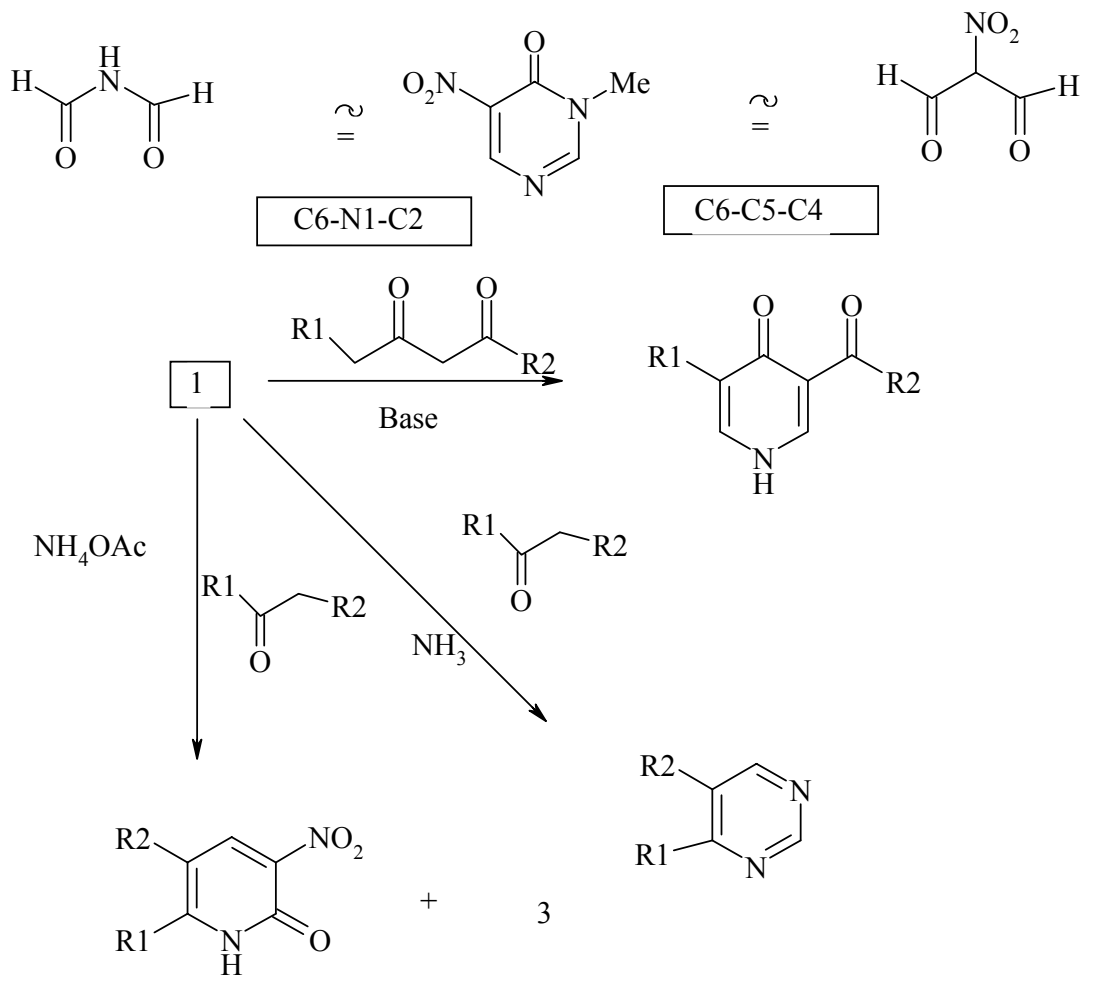

\section{Scheme 1}

The C2-N1-C6 moiety of $\mathbf{1}$ behaved as the activated diformylamine accompanied with elimination of anionic $N$-methylacetamide. 3,5-Difunctionalized 4-pyridones 2 were obtained by the reaction of pyrimidinone $\mathbf{1}$ with enolate ions of 1,3-dicarbonyl compounds. ${ }^{1}$ Treatment of $\mathbf{1}$ with ketones in the presence of ammonia also proceeded to give 4,5 -disubstituted pyrimidines $3{ }^{2}$ The yields of $\mathbf{3}$ were, however, low due to ammonolysis of $\mathbf{1}$ leading to nitroenamine $\mathbf{4 a} .{ }^{3}$ Use of ammonium acetate instead of ammonia as the nitrogen source overcame this disadvantage. ${ }^{4}$ Pyrimidines 3 were obtained in considerably improved yields under milder conditions. In addition, 5,6-disubstituted 3-nitro-2-pyridones 5 were also produced by the alternative ring transformation of $\mathbf{1}$. In this case, the C4-C5-C6 moiety of pyrimidinone $\mathbf{1}$ acted as the equivalent of $\alpha$-nitroformylacetic acid.

Meanwhile, carbamoylnitroenamine 4(see table) is an interesting sa similar pattern were observed (the ratio of integrals was $73: 23: 2: 2$ ). Each structure had two broad signals in the lower field. These signals were slowly diminished in $24 \mathrm{~h}$ with addition of $\mathrm{D}_{2} \mathrm{O}$. On the basis of ${ }^{1} \mathrm{H}-{ }^{1} \mathrm{H}$ COSY 2D NMR, one broad signal was related to the $N$-methyl group, and the other was related to both the $N$-methylene group and the doublet at $8.67 \mathrm{ppm}$. This olefinic proton had a large coupling constant $(14.1 \mathrm{~Hz})$ which was characteristic to the nitroenamine skeleton. ${ }^{6,8}$ Among six kinds of configuration and/or conformation bearing the intramolecular hydrogen bond(s) I-VI (Figure 1), ${ }^{9}$ I, III, IV and VI were plausible. 


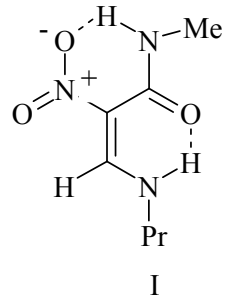<smiles>CCCn1ccc2c(c1=O)[N+](=O)NCN2O</smiles><smiles></smiles><smiles>CCCNC(=O)C1=CNC=[N+]([O-])C1</smiles><smiles></smiles><smiles></smiles>

Figure 1

Reaction of $\mathbf{1}$ with sterically hindered tert-butylamine afforded nitroenamine $\mathbf{4 c}$ in a good yield. Treatment of 1 with aqueous ammonia solution lead to 4a. Reaction of aromatic amines with 1 gave corresponding nitroenamines $\mathbf{4 d}-\mathbf{f}$.Aminolysis of pyrimidinone $\mathbf{1}$ proceeded even at room temperature though long reaction time was required. When 1.1 equimolar of amine was used, the yield of the nitroenamine was considerably lowered.This result indicated that more than two molecules of amines were necessary to decompose 1. o-Methylaniline revealed reduced reactivity compared with $p$-methyl derivative, and quantitative recovery of $\mathbf{1}$ was observed in the case of less nucleophilic $p$-nitroaniline (Table).

Table 1

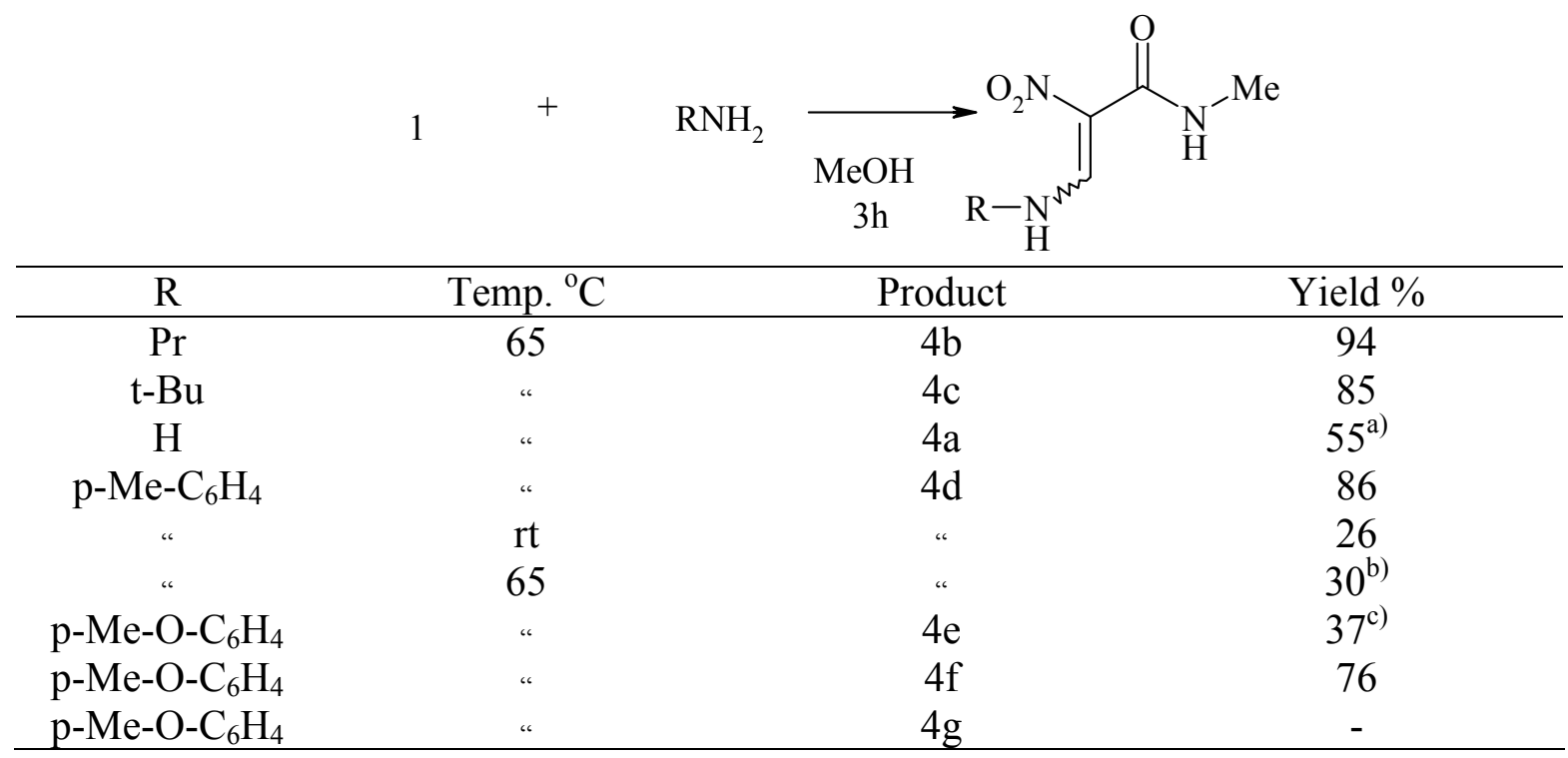

a) $25 \% \mathrm{NH} 3$ aq. was used. b) $1.1 \mathrm{mmol}$ of amines were used.

c) $5.5 \mathrm{mmol}$ of amines were used 
A plausible mechanism of the present aminolysis is illustrated in Scheme 3. The aminolysis of 1 is initiated with nucleophilic attack of amine at the 6-position, and the cleavage of the N1-C6 bond successively occurred. Deprotonation at the 6- or the 2-positions is considered not to occur since no product was detected on treatment of 1 with triethylamine under same conditions. The methanimidoyl group is eliminated as the amidine to yield nitroenamine $\mathbf{4}$ when intermediate $\mathbf{8}$ is attacked by a second molecule of the amine.
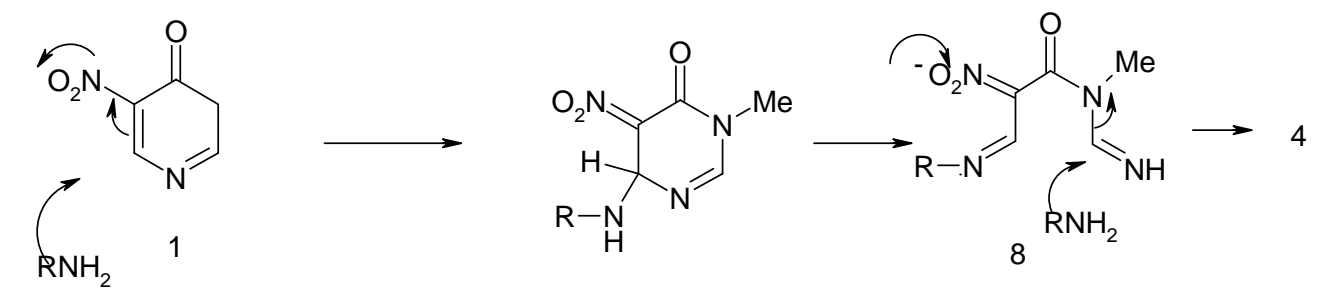

\section{Scheme 3}

Reactions of pyrimidinone 1 with diamines showed somewhat different reactivity. White precipitates were formed during the reactions using aliphatic diamines such as 1,2-diaminoethane or 1,3-diaminopropane. As there was no solvent dissolving these white solids, the structures have not been determined yet. In the reaction of isomeric pyrimidinone 6 with diamines, we isolated macrocycles which were formed by dimerization of aminolysis products. In consideration with this fact, there is possibility of these products to have similar large rings like 9 (Figure 2).

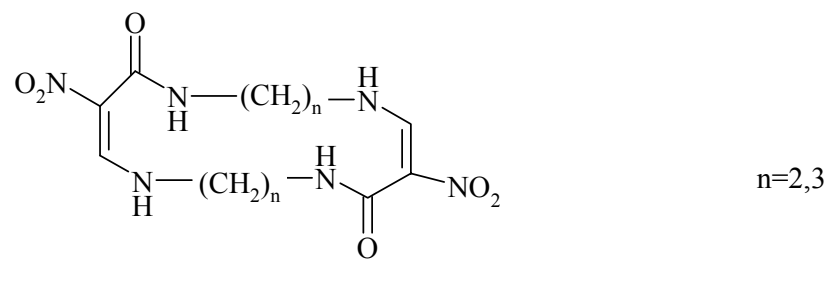

9

\section{Figure 2}

On the contrary, nitroenamine $\mathbf{4 h}$ was obtained in the reaction of $\mathbf{1}$ with 1,2-diaminobenzene (Scheme 4). Benzimidazole 10h was also obtained in addition to $\mathbf{4 h}$, it is obvious that pyrimidinone 1 behaved as the transferring agent of a $\mathrm{C} 1$ unit to diaminobenzene. Since isolated 4h was not converted to $10 \mathrm{~h}$ under the same conditions employed for aminolysis, benzimidazole 10h may be formed by the competitive intramolecular cyclization of the intermediate 8. 5,6Dimethyl benzimidazole 10i and corresponding nitroenamine $4 \mathbf{i}$ were similarly prepared from 1,2-diamino-4,5-dimethylbenzene. 


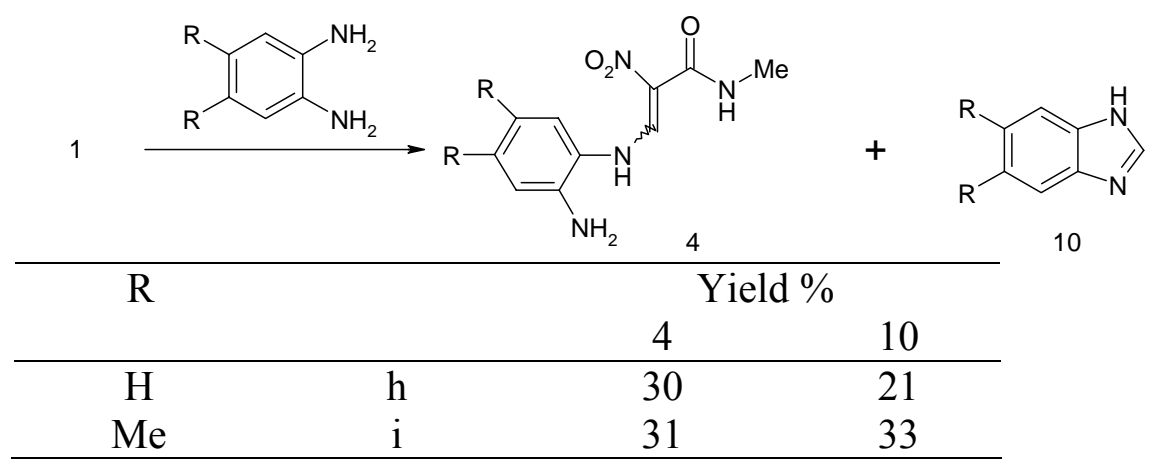

\section{Scheme 4}

Reactions of pyrimidinone $\mathbf{1}$ with aromatic and aliphatic secondary amines were also studied. $\mathrm{N}$ Methylaniline gave no positive result, and $\mathbf{1}$ was totally recovered. In the case of dipropylamine, unexpected products $4 \mathbf{a}$ and $4 \mathbf{j}(\mathrm{R}=\mathrm{Me})$ were obtained in 38 and $28 \%$ yields instead of dipropylamino derivative $\mathbf{1 1}$ (Figure 3). It seems that the nitroenamine $\mathbf{4 j}$ is derived from the reaction of $\mathbf{1}$ with methylamine generated by the decomposition of $\mathbf{1}$. If this is true, the yield of $4 \mathbf{j}$ is $56 \%$ based on $\mathbf{1}$. However, we have not found plain explanation for the isolation of $4 \mathbf{j}$. On the other hand, it is considered that the amino derivative $\mathbf{4 a}$ is produced under the mechanism shown in Scheme 5. Sterically hindered secondary amine attacks the less crowded 2-position of 1 to give adduct 12. The fission of $\mathrm{N} 1-\mathrm{C} 2$ bond and following methanolysis give nitroenamine $4 \mathbf{a}$.<smiles>C[14CH2]NC(=O)/C(=C\NC)[N+](=O)[O-]</smiles>

$4 \mathrm{j}$<smiles>CCCN(C=C(C(=O)O)C(=O)NNS(=O)(=O)c1ccccc1)CC</smiles>

11

\section{Figure 3}

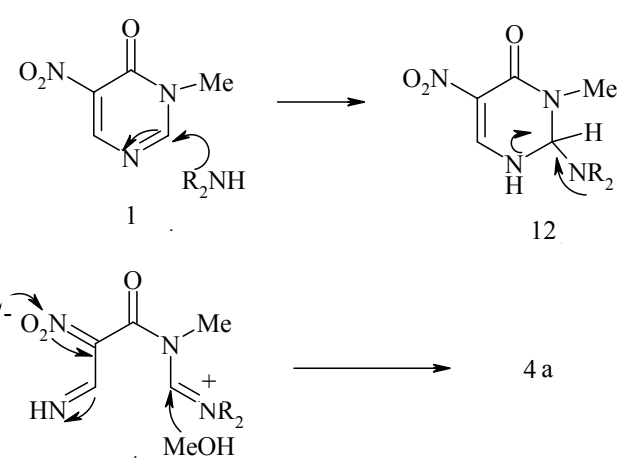

\section{Scheme 5}


As described above, nitropyrimidinone 1 was shown to be an excellent precursor of functionalized nitroenamines 4 . In the present reaction, modification of amino group is readily achieved by choosing required amine. Obtained nitroenamines $\mathbf{4}$ are useful synthetic intermediates for polyfunctionalized compounds. As one application to organic syntheses, conversion of $\mathbf{4 b}$ to polyfunctionalized pyridone $\mathbf{1 3}$ was studied. Treatment of nitroenamine $\mathbf{4 b}$ with enolate ion of ethyl 3-oxobutanoate afforded 5-ethoxycarbonyl-1,6-dimethyl-3-nitropyridin2(1H)-one (13). Pyridone 13 was formed by a series of Michael addition of the enolate ion to the electrophilic site of $\mathbf{4 b}$, elimination of propylamine and intramolecular attack of the carbamoyl anion to the acetyl group (Scheme 6). Investigations of other chemical transformations of nitroenamine 4 are in progress, and the results will be reported in due course.

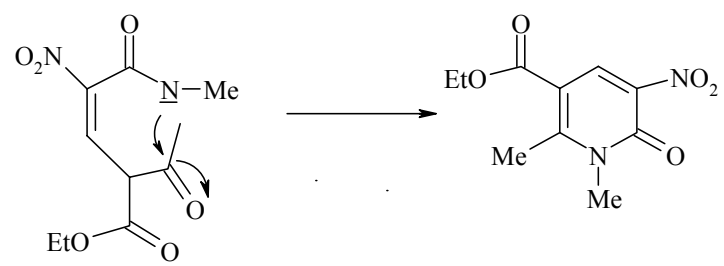

\section{Scheme 6}

\section{Experimental Section}

General Procedures. 3-Methyl-5-nitropyrimidin-4(3H)-one 1: Pyrimidinone 1 was obtained from 2-thiouracil by reduction, 10 methylation,10 and nitration2 with fuming $\mathrm{HNO}_{3}$ in $18 \mathrm{M}$ $\mathrm{H}_{2} \mathrm{SO}_{4}$ at $100{ }^{\circ} \mathrm{C}$ for $7 \mathrm{~h}$ in $43 \%$ overall yield.

Synthesis of nitroenamines 4. To a solution of pyrimidinone 1 (155 mg, $1.0 \mathrm{mmol})$ in methanol $(20 \mathrm{~mL})$, propylamine $(205 \mu \mathrm{L}, 2.5 \mathrm{mmol})$ was added, and the mixture was heated under reflux for $3 \mathrm{~h}$. After removal of methanol, the residue was extracted with hot hexane $(30 \mathrm{~mL} \times 3)$. The extract was concentrated to afford almost pure nitroenamine $\mathbf{4 b}$ (176 mg, $0.94 \mathrm{mmol}, 94 \%$ yield). Further purification was performed by recrystallization from hexane. Reactions of $\mathbf{1}$ with other primary amines except for ammonia were similarly conducted.

$\mathrm{N}$-Methyl-2-nitro-3-(propylamino)propenamide (4b). Colorless needles; mp 82-84 ${ }^{\circ} \mathrm{C}$; IR (Nujol) 3341, 1654, $1529 \mathrm{~cm}^{-1}$; ${ }^{1} \mathrm{H}$ NMR (400 MHz, $\mathrm{CDCl}_{3}, \mathrm{TMS}$ ). The largest amount of product (Product A): $\delta 1.00(\mathrm{t}, J=7.4 \mathrm{~Hz}, 3 \mathrm{H}), 1.65-1.75(\mathrm{~m}, 2 \mathrm{H}), 2.92(\mathrm{~d}, J=4.9 \mathrm{~Hz}, 3 \mathrm{H}), 3.42$ $(\mathrm{dt}, J=6.7,6.7 \mathrm{~Hz}), 8.67(\mathrm{~d}, J=14.1 \mathrm{~Hz}, 1 \mathrm{H}), 8.7-8.9\left(\mathrm{br}, 1 \mathrm{H}\right.$, exchangeable with $\left.\mathrm{D}_{2} \mathrm{O}, \mathrm{NHMe}\right)$, 10.6-11.1 (br, $1 \mathrm{H}$, exchangeable with $\mathrm{D}_{2} \mathrm{O},=\mathrm{CHN}$ HPr): The second largest amount of product: $\delta$ $1.01(\mathrm{t}, J=7.3 \mathrm{~Hz}, 3 \mathrm{H}), 1.7-1.8(\mathrm{~m}, 2 \mathrm{H}), 2.95(\mathrm{~d}, J=4.7 \mathrm{~Hz}, 2 \mathrm{H}), 3.53(\mathrm{dt}, J=6.7,6.7 \mathrm{~Hz}), 8.54$ $(\mathrm{d}, J=15.2 \mathrm{~Hz}, 1 \mathrm{H}), 8.6-8.8$ (br, $1 \mathrm{H}$, exchangeable with $\mathrm{D}_{2} \mathrm{O}, \mathrm{N} \underline{\mathrm{HMe}}$ ), 9.8-10.1 (br, $1 \mathrm{H}$, exchangeable with $\mathrm{D}_{2} \mathrm{O},=\mathrm{CHN} \underline{\mathrm{H} P r}$ ): In addition, two sets of signals having a similar pattern and 
chemical shifts were observed, however, they were too small to be wholly analyzed.; ${ }^{13} \mathrm{C}$ NMR (100 MHz, $\mathrm{CDCl}_{3}$, TMS) Product A: $\delta$ 165.1, 157.4, 117.2, 52.4, 25.6, 23.6, 11.0: Product B; 161.7, 154.6, 52.6, 26.4, 23.6, 10.9 (one signal was hidden by noise). Anal. Calcd. for $\mathrm{C}_{7} \mathrm{H}_{13} \mathrm{~N}_{3} \mathrm{O}_{3}$ : C, 44.91; H, 7.00; N, 22.45\%. Found: C, 45.12; H, 7.16; N, 21.99\%.

3-t-Butylamino- $\mathrm{N}$-methyl-2-nitropropenamide (4c). Colorless granules; mp $62-63{ }^{\circ} \mathrm{C}$; IR (Nujol) 1659, 1641, 1520, $1338 \mathrm{~cm}^{-1}$; ${ }^{1} \mathrm{H} \mathrm{NMR}$ (400 MHz, $\mathrm{CDCl}_{3}$, TMS) All signals of each four products $\mathrm{A}-\mathrm{D}$ were obviously recognized except for the combined broad $\mathrm{NH}$ signal at $\delta$ 8.7-9.0. The ratio of A-D was $63: 17: 11: 9$. Product A $\delta 1.42(\mathrm{~s}, 9 \mathrm{H}), 2.92(\mathrm{~d}, J=4.8 \mathrm{~Hz}$, $3 \mathrm{H}), 8.77$ (d, $J=14.6 \mathrm{~Hz}, 1 \mathrm{H}), 8.7-9.0(\mathrm{br}), 11.0-11.4(\mathrm{br}, 1 \mathrm{H})$ : Product B $\delta 1.47(\mathrm{~s}, 9 \mathrm{H}), 2.95$ $(\mathrm{d}, J=4.5 \mathrm{~Hz}, 3 \mathrm{H}), 8.66(\mathrm{~d}, J=15.1 \mathrm{~Hz}, 1 \mathrm{H}), 8.7-9.0$ (br), 10.1-10.4 (br, 1H): Product C $\delta 1.43$ (s, 9H), 2.96 (d, $J$ value could not be measured, 3H), 8.77 (d, $J=15.7 \mathrm{~Hz}, 1 \mathrm{H}), 8.7-9.0$ (br), 9.8-10.1 (br, 1H): Product D $\delta 1.45$ (s, 9H), 2.87 (d, $J=4.7 \mathrm{~Hz}, 3 \mathrm{H}), 8.18$ (d, J=15.3 Hz, 1H), 8.7-9.0 (br), 9.5-9.7 (br, 1H). Anal. Calcd. for $\mathrm{C}_{8} \mathrm{H}_{15} \mathrm{~N}_{3} \mathrm{O}_{3}: \mathrm{C}, 47.75 ; \mathrm{H}, 7.51 ; \mathrm{N}, 20.88 \%$. Found: C, 47.13; H, 7.50; N, 20.74\%.

$\mathrm{N}$-Methyl-3-(4-methylphenyl)amino-2-nitropropenamide (4d). Yellow needles; mp $118-125^{\circ} \mathrm{C}$ (dec.); IR (Nujol) 1627, 1601, 1537, $1516 \mathrm{~cm}^{-1} ;{ }^{1} \mathrm{H}$ NMR (400 MHz, $\mathrm{CDCl}_{3}$, TMS).Data of the largest amount of product are shown. $\delta 2.37(\mathrm{~s}, 3 \mathrm{H}), 2.98(\mathrm{~d}, J=4.8 \mathrm{~Hz}, 3 \mathrm{H})$, $7.17(\mathrm{~d}, J=6.9 \mathrm{~Hz}, 2 \mathrm{H}), 7.21(\mathrm{~d}, J=6.9 \mathrm{~Hz}, 2 \mathrm{H}), 8.75-8.9(\mathrm{br}, 1 \mathrm{H}), 9.13(\mathrm{~d}, J=13.7 \mathrm{~Hz}, 1 \mathrm{H})$, 12.4-12.7 (br, $1 \mathrm{H}$, two maxima were observed). Anal. Calcd. for $\mathrm{C}_{11} \mathrm{H}_{13} \mathrm{~N}_{3} \mathrm{O}_{3}$ : C, 56.16; $\mathrm{H}, 5.57$; N, 17.86\%. Found: C, 56.35; H, 5.70; N, 17.79\%.

$\mathrm{N}$-Methyl-3-(2-methylphenyl)amino-2-nitropropenamide (4e). Yellow needles; mp 154-159 ${ }^{\circ} \mathrm{C}$ (dec.); IR (Nujol) 3379, 1626, $1539 \mathrm{~cm}^{-1} ;{ }^{1} \mathrm{H}$ NMR (400 MHz, $\mathrm{CDCl}_{3}$, TMS) Data of the largest amount of product were shown. $\delta 2.43(\mathrm{~s}, 3 \mathrm{H}), 3.00(\mathrm{~d}, J=4.9 \mathrm{~Hz}, 3 \mathrm{H}), 7.0-7.4$ (m, 4H), 8.75-8.9 (br, 1H), $9.16(\mathrm{~d}, J=13.3 \mathrm{~Hz}, 1 \mathrm{H}), 12.7-12.9$ (br, 1H, two maximas were observed). Anal. Calcd. for $\mathrm{C}_{11} \mathrm{H}_{13} \mathrm{~N}_{3} \mathrm{O}_{3}$ : C, 56.16; H, 5.57; N, 17.86\%. Found: C, 55.78; H, $5.61 ; \mathrm{N}, 17.74 \%$.

3-(4-Methoxyphenyl)amino- $N$-methyl-2-nitropropenamide (4f). Yellow needles; mp 120-124 ${ }^{\circ} \mathrm{C}$ (dec.); IR (Nujol) 3390, 1628, 1601, $1541 \mathrm{~cm}^{-1} ;{ }^{1} \mathrm{H}$ NMR (400 MHz, $\mathrm{CDCl}_{3}$, TMS) Data of the largest amount of product were shown. $\delta 2.98(\mathrm{~d}, J=4.5 \mathrm{~Hz}, 3 \mathrm{H}), 3.83(\mathrm{~s}, 3 \mathrm{H}), 6.95$ $(\mathrm{d}, J=8.9 \mathrm{~Hz}, 2 \mathrm{H}), 7.19(\mathrm{~d}, J=8.9 \mathrm{~Hz}, 2 \mathrm{H}), 8.75-8.9(\mathrm{br}, 1 \mathrm{H}), 9.03(\mathrm{~d}, J=13.7 \mathrm{~Hz}, 1 \mathrm{H})$, 12.5-12.8 (br, 1H). Anal. Calcd. for $\mathrm{C}_{11} \mathrm{H}_{13} \mathrm{~N}_{3} \mathrm{O}_{4}$ : C, 52.59; H, 5.22; N, 16.73\%. Found: C, 52.38; H, 5.09; N, 16.80\%.

Ammonolysis of pyrimidinone 1. To a solution of pyrimidinone 1 (155 $\mathrm{mg}, 1.0 \mathrm{mmol})$ in methanol $(20 \mathrm{~mL}), 25 \%$ aqueous ammonia $(170 \mu \mathrm{L}, 2.5 \mathrm{mmol})$ was added, and the mixture was heated under reflux for $3 \mathrm{~h}$. After removal of methanol, the residue was washed with $\mathrm{CHCl}_{3}$ $(30 \mathrm{~mL})$ to afford almost pure nitroenamine $4 \mathbf{a}(80 \mathrm{mg}, 0.55 \mathrm{mmol}, 55 \%$ yield $)$. Further purification was performed by recrystallization from ethanol.

3-Amino- $\boldsymbol{N}$-methyl-2-nitropropenamide (4a). Orange needles; mp $179-182{ }^{\circ} \mathrm{C}$; IR (Nujol) 3384, 3287, 1647, $1509 \mathrm{~cm}^{-1}$; ${ }^{1} \mathrm{H}$ NMR (400 MHz, DMSO-d 6 , TMS) $\delta 2.75(\mathrm{~d}, J=4.5 \mathrm{~Hz}, 3 \mathrm{H}$ ), 
8.64 (br.s, 1H), 8.9-9.5 (br, 2H), 9,5-10.0 (br, 1H). Anal. Calcd. for $\mathrm{C}_{4} \mathrm{H}_{7} \mathrm{~N}_{3} \mathrm{O}_{3}$ : C, 33.10; $\mathrm{H}$, 4.87 ; N, 28.96\%. Found: C, 33.38; H, 4.77; N, 28.74\%.

Reactions of pyrimidinone 1 with aromatic diamines. To a solution of pyrimidinone 1 (155 mg, $1.0 \mathrm{mmol})$ in methanol $(20 \mathrm{~mL})$, 1,2-diaminobenzene (119 mg, $1.1 \mathrm{mmol})$ was added, and the mixture was heated under reflux for $3 \mathrm{~h}$. After removal of methanol, the residue was recrystallized from methanol to give nitroenamine $\mathbf{4 h}(73 \mathrm{mg}, 0.31 \mathrm{mmol}, 31 \%$ yield). The mother liquor was concentrated, and the residue was column chromatographed on silica gel yielding benzimidazole ( $25 \mathrm{mg}, 0.21 \mathrm{mmol}$, eluted with ethyl acetate / ethanol = $2 / 1)$. Reactions of 1 with 1,2-diamino-4,5-dimethylbenzene was similarly conducted. Structures of benzimidazoles $\mathbf{1 0 h}$ and 10i were confirmed by comparing physical and spectral data with commercially available authentic samples.

3-(2-Aminophenyl)amino- $N$-methyl-2-nitropropenamide (4h). Orange needles; $\mathrm{mp}$ 150-151 ${ }^{\circ} \mathrm{C}$; IR (Nujol) 3361, 1626, 1603, $1277 \mathrm{~cm}^{-1} ;{ }^{1} \mathrm{H}$ NMR (400 MHz, DMSO-d 6 , TMS) Data of the largest amount of product were shown. $\delta 2.78(\mathrm{~d}, J=4.4 \mathrm{~Hz}, 3 \mathrm{H}), 5.08$ (br.s, $2 \mathrm{H}$ ), $6.67(\mathrm{dd}, J=7.8,7.8 \mathrm{~Hz}, 1 \mathrm{H}), 6.81(\mathrm{~d}, J=7.8 \mathrm{~Hz}, 1 \mathrm{H}), 6.99$ (dd, $J=7.8,7.8 \mathrm{~Hz}, 1 \mathrm{H}), 7.30$ (d, $J$ $=7.8 \mathrm{~Hz}, 1 \mathrm{H}), 8.75-8.85$ (br, $1 \mathrm{H}$, a shoulder was observed.), $8.96(\mathrm{~d}, J=13.5 \mathrm{~Hz}, 1 \mathrm{H}), 12.34$ (br.d, $J=13.5 \mathrm{~Hz}, 1 \mathrm{H}$ ). Anal. Calcd. for $\mathrm{C}_{10} \mathrm{H}_{12} \mathrm{~N}_{4} \mathrm{O}_{3}$ : C, 50.84; H, 5.12; N, 23.72\%. Found: C, $50.90 ; \mathrm{H}, 5.15 ; \mathrm{N}, 23.73 \%$.

3-(2-Amino-4,5-dimethylphenyl)amino- $\boldsymbol{N}$-methyl-2-nitropropenamide (4i). Orange needles; mp 215-217 ${ }^{\circ} \mathrm{C}$; IR (Nujol) 3383, 3327, 3250, 1628, 1541, $1290 \mathrm{~cm}^{-1}$; ${ }^{1} \mathrm{H}$ NMR (400 MHz, DMSO- $d_{6}$, TMS) Data of the largest amount of product were shown. $\delta 2.23(\mathrm{~s}, 3 \mathrm{H}), 2.24(\mathrm{~s}, 3 \mathrm{H})$, $2.94(\mathrm{~d}, J=4.4 \mathrm{~Hz}, 3 \mathrm{H}), 4.97$ (br.s, 2H), 6.79 (s, 1H), 7.28 (s, 1H), 8.95-9.05 (br, 1H, The top of the signal was slightly splitting), 9.08 (d, $J=13.4 \mathrm{~Hz}, 1 \mathrm{H}), 12.53$ (br.d, $J=13.4 \mathrm{~Hz}, 1 \mathrm{H}$ ). Anal. Calcd. for $\mathrm{C}_{12} \mathrm{H}_{16} \mathrm{~N}_{4} \mathrm{O}_{3}$ : C, 54.54; H, 6.10; N, 21.20\%. Found: C, 54.70; H, 6.09; N, 21.17\%.

Reactions of pyrimidinone 1 with dipropylamine. To a solution of pyrimidinone 1 (155 $\mathrm{mg}$, $1.0 \mathrm{mmol})$ in methanol $(20 \mathrm{~mL})$, dipropylamine $(343 \mu \mathrm{L}, 2.5 \mathrm{mmol})$ was added, and the mixture was heated under reflux for $3 \mathrm{~h}$. After removal of methanol, the residue was extracted with hot hexane $(30 \mathrm{~mL} \times 3)$. The extract was concentrated to afford almost pure nitroenamine $\mathbf{4 j}$ ( $45 \mathrm{mg}$, $0.28 \mathrm{mmol}, 28 \%$ yield). The residue was washed with $\mathrm{CHCl}_{3}(30 \mathrm{~mL})$ to furnish nitroenamine $4 \mathbf{a}$ (55 mg, $0.38 \mathrm{mmol}, 38 \%$ yield). Further purification was performed by recrystallization from ethanol.

N-Methyl-3-methylamino-2-nitropropenamide (4j). Pale yellow needles; mp $177-179{ }^{\circ} \mathrm{C}$; IR (Nujol) 3365, 3254, 1676, 1618, $1534 \mathrm{~cm}^{-1}$; ${ }^{1} \mathrm{H} \mathrm{NMR}$ (400 MHz, $\mathrm{CDCl}_{3}$, TMS) Signals of two products $\mathrm{A}$ and $\mathrm{B}$ could be assigned except for the combined broad NH signal at $\delta 8.65-8.85$. The ratio of A and B was $78: 22$. Product A $\delta 2.92(\mathrm{~d}, J=4.9 \mathrm{~Hz}, 3 \mathrm{H}), 3.26(\mathrm{~d}, J=5.2 \mathrm{~Hz}, 3 \mathrm{H})$, $8.66(\mathrm{~d}, J=14.1 \mathrm{~Hz}, 1 \mathrm{H}), 8.65-8.85(\mathrm{br}), 10.5-10.9(\mathrm{br}, 1 \mathrm{H})$ : Product B $\delta 2.95$ (d, $J=4.8 \mathrm{~Hz}$, $3 \mathrm{H}), 3.36$ (d, $J=5.2 \mathrm{~Hz}, 3 \mathrm{H}), 8.54$ (d, $J=15.2 \mathrm{~Hz}, 1 \mathrm{H}), 8.65-8.85$ (br), 9.6-10.0 (br, 1H) Anal. Calcd. for $\mathrm{C}_{5} \mathrm{H}_{9} \mathrm{~N}_{3} \mathrm{O}_{3}$ : C, 37.72; H, 5.71; N, 26.41\%. Found: C, 38.05; H, 5.69; N, 26.05\%. 
Reactions of nitroenamine $4 \mathrm{~b}$ with enolate ion of ethyl 3-oxobutanoate. The sodium enolate was prepared from ethyl 3-oxobutanoate $(0.64 \mathrm{~mL}, 5.0 \mathrm{mmol})$ and sodium ethoxide $(5.0 \mathrm{mmol})$ in ethanol $(20 \mathrm{~mL})$. After removal of ethanol, the resultant enolate was dissolved in pyridine (20 $\mathrm{mL})$. The solution was added to a solution of nitroenamine $\mathbf{4 b}(187 \mathrm{mg}, 1.0 \mathrm{mmol})$ in pyridine $(20 \mathrm{~mL})$, and the mixture was heated at $80{ }^{\circ} \mathrm{C}$ for $3 \mathrm{~h} .1 \mathrm{M} \mathrm{HCl}(10 \mathrm{~mL}, 10 \mathrm{mmol})$ was added, and the mixture was extracted with $\mathrm{CHCl}_{3}(30 \mathrm{~mL}$ x 3$)$. The organic layer was dried over $\mathrm{MgSO}_{4}$, and concentrated. The residue was column chromatographed on silica gel to afford pyridone $\mathbf{1 3}$ (137 mg, $0.57 \mathrm{mmol}, 57 \%$ yield, eluent: $\mathrm{CHCl}_{3} /$ ethyl acetate $=3 / 1$ ).

5-Ethoxycarbonyl-1,6-dimethyl-3-nitropyridin-2(1H)-one (13). Pale yellow powder; mp 99-100 ${ }^{\circ} \mathrm{C}$; IR (Nujol) 1720, 1693, 1527, $1336 \mathrm{~cm}^{-1}$; ${ }^{1} \mathrm{H}$ NMR (400 MHz, DMSO-d 6 , TMS) $\delta$ $1.31(\mathrm{t}, J=7.1 \mathrm{~Hz}, 3 \mathrm{H}), 2.84(\mathrm{~s}, 3 \mathrm{H}), 3.61(\mathrm{~s}, 3 \mathrm{H}), 4.28(\mathrm{q}, J=7.1 \mathrm{~Hz}, 2 \mathrm{H}), 8.72(\mathrm{~s}, 1 \mathrm{H})$. Anal. Calcd. for $\mathrm{C}_{10} \mathrm{H}_{12} \mathrm{~N}_{2} \mathrm{O}_{5}$ : C, 50.00; H, 5.04; N, 11.66\%. Found: C, 50.00; H, 4.99; N, 11.57\%.

\section{References}

1. Nishiwaki, N.; Tohda, Y.; Ariga, M. Synthesis, 1997, 1277.

2. Nishiwaki, N.; Matsunaga, T.; Tohda, Y.; Ariga, M. Heterocycles, 1994, 38, 249.

3. Nishiwaki, N.; Mizukawa, Y.; Ohta, M.; Terai, R.; Tohda, Y.; Ariga, M. Heterocyclic Commun., 1996, 2, 21.

4. (a) Nishiwaki, N.; Adachi, T.; Matsuo, K.; Wang, H.-P.; Matsunaga, T.; Tohda, Y.; Ariga, M. J. Chem. Soc., Perkin Trans. 1, 27. (b) Nishiwaki, N.; Matsuo, K.; Wang, H.-P.; Tohda, Y.; Ariga, M. J. Chem. Soc., Perkin Trans. 1, 1997, 2261.

5. (a) Perekalin, V. V.; Lipina, E. S.; Berestovitskaya, V. M.; Efremov, D. A. Nitroalkenes, Conjugated Nitro Compounds, Wiley, New York, 1994, 210. (b) Rajappa, S Tetrahedron, 1981, 37, 1453.

6. (a) Nishiwaki, N.; Tohda, Y.; Ariga, M. Bull. Chem. Soc. Jpn., 1996, 69, 1997. (b) Nishiwaki, N.; Wakamura, E.; Nishida, Y.; Tohda, Y.; Ariga, M. Heterocyclic Commun., 1996, 2, 129.

7. Ariga, M.; Nishiwaki, N.; Miwa, Y.; Tani, K.; Tohda, Y. Heterocycles, 1997, 44, 81.

8. (a) Bedford, C. D.; Nielsen, A. T. J. Org. Chem., 1979, 44, 633. (b) Fetell, A. I.; Feuer, H. J. Org. Chem., 1978, 43, 497. (c) Wolfbeis, O. S. Chem. Ber., 1977, 110, 2480.

9. (a) Chiara, J.-L.; Gómez-Sánchez, A.; Hidalgo, F.-J. J. Chem. Soc., Perkin Trans. 2, 1988, 1691. (b) Marcos, E. S.; Maraver, J. J.; Chiara, J.-L.; Gómez-Sánchez, A. J. Chem. Soc., Perkin Trans. 2, 1988, 2059.

10. Bauer, L.; Wright, G. E.; Mikrut , B. A.; Bell, C. L. J. Heterocycl. Chem., 1965, 2, 447. 